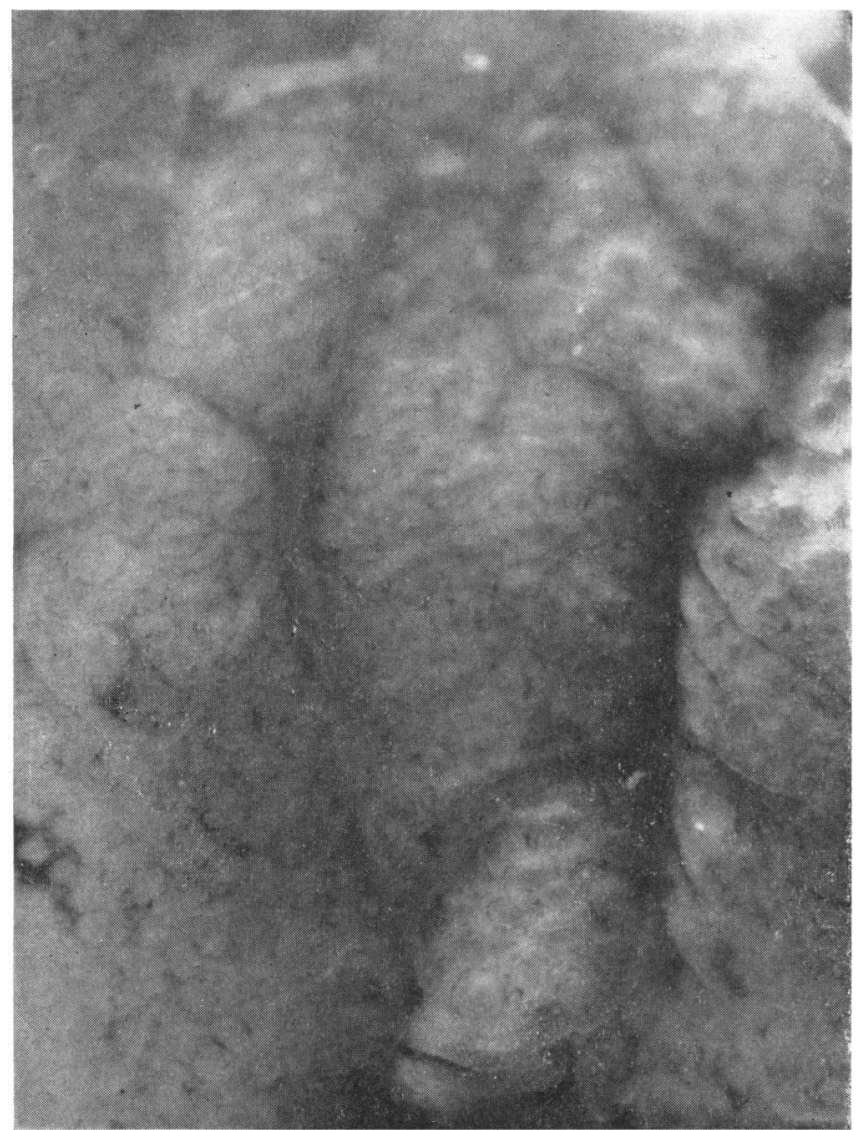

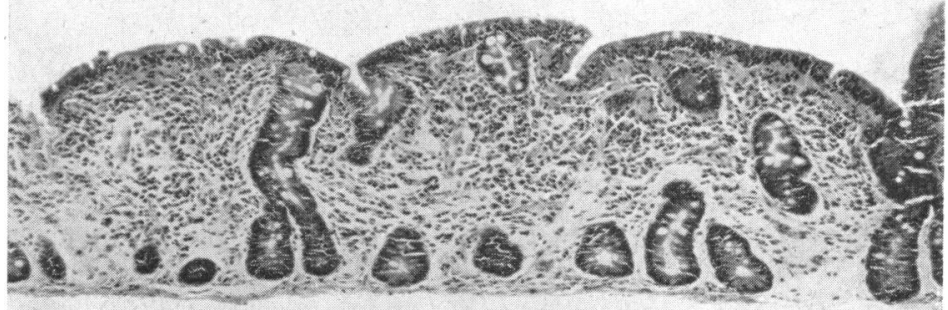

FIG. 2

FIg. 1.-Flat mucosa with mosaic pattern from the jejunum of a patient (J.S.) aged 30 and symptom-free for 20 years. $(\times 35$.

FIG. 2.- Histological section of mucosa shown in Fig. 1. (H. and E. $\times 85$.)

RICHARD C. R. CONNOR: HEART DAMAGE ASSOCIATED WITH INTRACRANIAL LESIONS

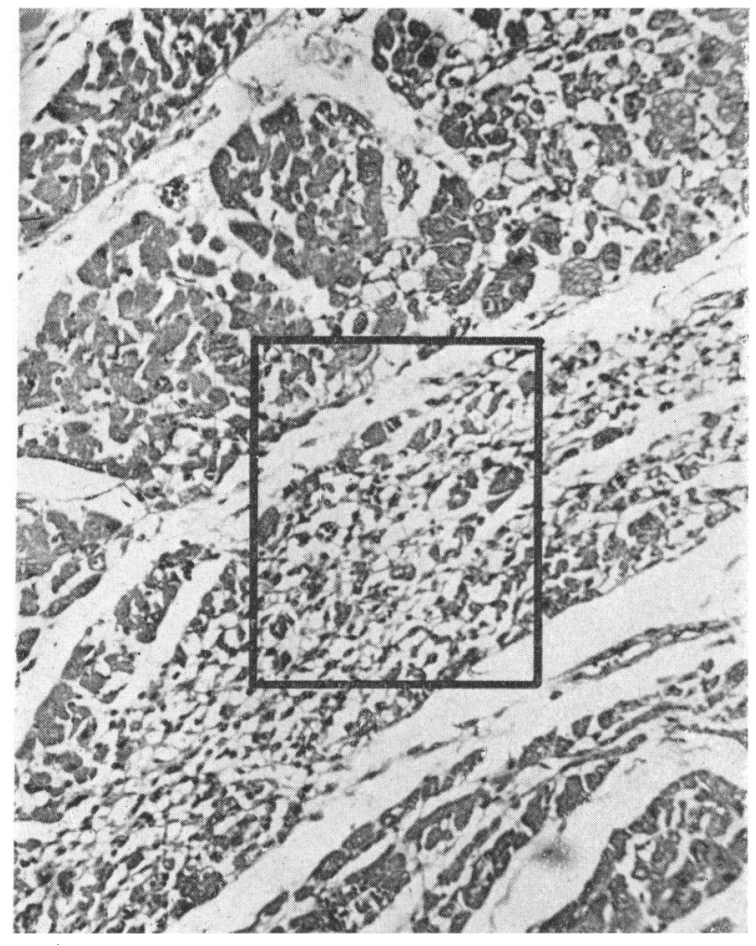

FIG. 1.-Myocardium. There is normal muscle above and below an area showing myocytolysis. Empty sarcolemmal sheaths and bare nuclei can be seen. (Haemalum and eosin.

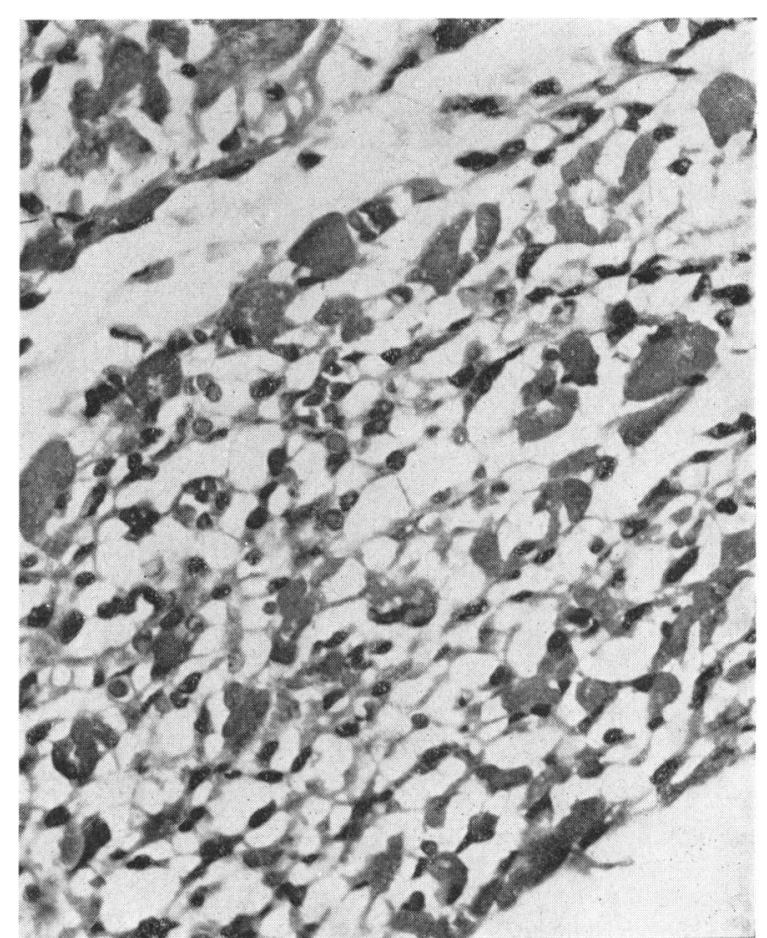

FIG. 2.-Myocardium. Marked area of lesion in Fig. 1 (K78/ 65) at higher magnification. In the upper part of the picture there is a damaged vacuolated muscle fibre. Scattered remnants of fibres are seen in the lesion. Sarcolemmal sheaths with and without nuclei are shown. Polymorphs are not present. (Haemalum and eosin. $\times 400$.) 
no alternative if the penicillin has to be stopped because of haemolysis. Though no reports exist regarding in-vivo survival of cells sensitized with ampicillin, methicillin, and cephaloridine, Nesmith and Davis (1968) reported that ${ }^{51} \mathrm{Cr}$-labelled red cells sensitized with cephalothin had a $\mathrm{T} \frac{1}{2}$ of 135 minutes when injected into a patient with penicillin-induced haemolytic anaemia.

We found, as did Bird (1960), that the antibody had no effect on the in-vitro bactericidal activity of penicillin.

Incidence of Haemolytic Anaemia after High-Dose Penicillin Therapy.-The incidence of penicillin immune haemolytic anaemia in patients receiving high doses of penicillin is not known, but it is probably not common. We have observed four other patients who were receiving 20 mega units a day for up to six weeks. All gave negative direct antiglobulin tests, and no antipenicillin antibodies were detected in their sera, even though penicillin was easily detectable on the red cells. None of the patients developed signs of haemolysis during therapy. Petz and Fudenberg (1966) briefly mentioned a patient with a positive direct antiglobulin test and penicillin antibodies in the serum, in whom there was no evidence of increased destruction of the red cells.

We thank Professor C. C. Booth and Professor J. P. Shillingford for permission to publish case histories of the two patients, Mrs. Jane Farndon and Mrs. Pamela Lisamore for skilled technical assistance, Mrs, Ruth Mitcheson for measuring the penicillin serum concentrations, and Professor J. V. Dacie for his helpful criticism of this paper.

\section{REFERENCES}

Beardwell, C. G. (1964). Proc. roy. Soc. Med., 57, 332.

Bird, G. W. G. (1960). F. clin. Path., 13, 51.

Clayton, E. M., Altshuler, J., and Bove, J. R. (1965). Amer. f. clin. Path., 44, 648

de Weck, A. L. (1964). Nature (Lond.), 202, 975.

Dawson, R. B., jun., and Segal, B. L. (1966). Arch. intern. Med., 118, 575 .

Fujii, R., Grossman, M., and Ticknor, W. (1961). Pediatrics, 28, 662.

Josephson, A. S., and Kaplan, A. P. (1967). F. Immunol., 98, 293.

Lai, M., Rosner, F., and Ritz, N. D. (1966). Y. Amer. med. Ass., 198 483 .

Landsteiner, K., and Miller, C. P., jun. (1925). F. exp. Med., 42, 853.

Levine, B. B. (1965). Fed. Proc., 24, 45.

Levine, B. B., Fellner, M. J., Levytska, V., Franklin, E. C., and Alisberg, N. (1966a). 7. Immunol., 96, 719 .

Levine, B. B., and Redmond, A. (1966). Information Exchange Group, No. 5 .

Levine, B. B., Redmond, A. P., Fellner, M. J., Voss, H. E., and Levytska, V. (1966b). F. clin. Invest., 45, 1895 .

Ley, A. B., Caham, A., and Mayer, K. (1959). In Proceedings of the Seventh Congress of the International Society of Blood Transfusion, p. 539. Basel.

Mollison, P. L. (1967). Blood Transfusion in Clinical Medicine, 4th ed. Oxford.

Nesmith, L. W., and Davis, J. W. (1968). 7. Amer. med. Ass., 203, 27. Petz, L. D., and Fudenberg, H. H. (1966). New Engl. J. Med., 274, 171. Strumia, P. V., and Raymond, F. D. (1962). Arch. intern. Med., 109, 603.

Swanson, M. A., Chanmougan, D., and Schwartz, R. S. (1966). New Engl. 7. Med., 274, 178.

Van Arsdel, P. P., jun., and Gilliland, B. C. (1965). F. Lab. clin. Med., 65, 277.

\title{
Heart Damage Associated with Intracranial Lesions
}

\author{
RICHARD C. R. CONNOR,* M.B., B.S.
}

[With Special Plate facing Page 8]

Brit. med. F., 1968, 3, 29-31

\begin{abstract}
Cummary : Focal myocytolysis, a form of myocardial $\checkmark$ damage, has been found to occur in about $8 \%$ of patients dying of intracranial lesions. Electrocardiographic abnormalities in patients with brain damage may be due to this. The cause of focal myocytolysis remains unknown, but if it could be prevented it might avert the patient's death from cardiac arrest or arrhythmia. Moreover, more than a minimal degree of this type of damage to the heart might make it unsuitable for transplantation.
\end{abstract}

\section{Introduction}

It has been known for at least 30 years (Aschenbrenner and Bodechtel, 1938) that brain lesions may be accompanied by abnormalities in the electrocardiogram (E.C.G.). Post-mortem examination of hearts from such patients has not usually shown any appreciable abnormality, and a vague impression has arisen that E.C.G. changes are due to neural influences rather than to actual myocardial changes (Cropp and Manning, 1960). It is therefore important to record that myocardial damage does occur in patients with brain lesions. One type of this damage is focal myocytolysis (Schlesinger and Reiner, 1955), which is the subject of this paper. If such damage is more than minimal it might render the heart unsuitable for transplantation.

\footnotetext{
* Assistant Pathologist, Pathology Department, Western Infirmary,
}

\section{Material and Methods}

From September 1964 until April 1966231 necropsies were performed in the West of Scotland Neurosurgical Unit. The four main causes of death were intracranial haemorrhage $35 \%$, intracranial tumours $25 \%$, head injuries $20 \%$, and intracranial infection $15 \%$.

Blocks of ventricular myocardium were fixed in neutral formol saline $(10 \%)$ and double-embedded by the method of Russell (1956). During the period of this study two transverse slices of most hearts were taken across both ventricles, one about $3 \mathrm{~cm}$. from the apex and the other near the atrioventricular junction. These slices were then divided into multiple blocks. From 18 cases with myocytolysis 170 blocks of myocardium were examined. Paraffin sections were stained with haemalum and eosin and Masson's trichrome method.

Correlation of the findings with E.C.G. changes is unfortunately impossible. As the neurosurgical unit is not part of a general hospital, E.C.G.s are not performed routinely.

\section{Results}

Examination of the 231 hearts showed that 18 had foci of myocytolysis though significant abnormality had not been seen on naked-eye inspection. Of the 170 blocks from these 18 cases 
101 showed this lesion; some of the sections contained only one or two small foci. Most of the foci were found in the left ventricle rather than the right, but the distribution of damage in the muscle was random. There seemed to be no predilection for the subendocardial zone ; indeed, many of the lesions were subepicardial. The atrial muscle was not examined.

Thirteen of the patients died from intracranial haemorrhage, two from intracranial infection, and one each of trauma, tumour, and cerebral infarction. Nine of the patients were under 50 years of age, seven were in the sixth decade, and two were older. Cases occurred in every decade. Only two of the cases were without evidence of raised intracranial pressure or midline shift at necropsy. Details of the cases are shown in the Table.

Summary of Cases of Focal Myocytolysis

\begin{tabular}{|c|c|c|c|c|c|c|}
\hline Case & Sex & Age & $\begin{array}{l}\text { Raised } \\
\text { Intra- } \\
\text { cranial } \\
\text { Pressure }\end{array}$ & $\begin{array}{l}\text { Survival } \\
\text { After } \\
\text { Ictus } \\
\text { (Days) }\end{array}$ & $\begin{array}{l}\text { Coronary } \\
\text { Stenosis }\end{array}$ & Cause of Death \\
\hline $121 / 64$ & $\mathbf{F}$ & 61 & + & 7 & + & Ruptured vertebral \\
\hline $192 / 64$ & $\mathbf{F}$ & 38 & + & 5 & - & Hypertensive cerebral \\
\hline $\begin{array}{l}70 / 65 \\
78 / 65 \\
95 / 65 \\
98 / 65\end{array}$ & $\begin{array}{l}\mathbf{M} \\
\mathbf{M} \\
\mathbf{M} \\
\mathbf{M}\end{array}$ & $\begin{array}{l}11 \\
60 \\
26 \\
21\end{array}$ & $\begin{array}{l}+ \\
+ \\
+ \\
+\end{array}$ & $\begin{array}{l}2 \\
\mathbf{4} \\
\mathbf{7} \\
\mathbf{5}\end{array}$ & $\begin{array}{l}\bar{z} \\
\bar{z}\end{array}$ & $\begin{array}{l}\text { Severe brain lacerations } \\
\text { Ruptured aneurysm } \\
\text { Ruptured aneurysm } \\
\text { Cerebral abscess and } \\
\text { meningitis }\end{array}$ \\
\hline $\begin{array}{r}86 / 65 \\
112 / 65 \\
122 / 65 \\
125 / 65 \\
128 / 65\end{array}$ & $\begin{array}{l}\mathbf{F} \\
\mathbf{M} \\
\mathbf{F} \\
\mathbf{M} \\
\mathbf{F}\end{array}$ & $\begin{array}{l}58 \\
56 \\
46 \\
16 \\
54\end{array}$ & $\begin{array}{l}+ \\
+ \\
+ \\
+ \\
+\end{array}$ & $\begin{array}{l}4 \\
5 \\
6 \\
7 \\
4\end{array}$ & $\begin{array}{l}\bar{z} \\
\bar{z}\end{array}$ & $\begin{array}{l}\text { Ruptured aneurysm } \\
\text { Ruptured aneurysm } \\
\text { Ruptured aneurysm } \\
\text { Craniopharyngioma } \\
\text { Hypertensive intra- } \\
\text { cerebral haemorrhage }\end{array}$ \\
\hline $135 / 65$ & $\mathbf{M}$ & 28 & + & 5 & - & Haemorrhage into \\
\hline $\begin{array}{l}2 / 66 \\
3 / 66 \\
7 / 66\end{array}$ & $\begin{array}{l}\mathbf{M} \\
\mathbf{F}\end{array}$ & $\begin{array}{r}42 \\
4 \\
58\end{array}$ & $\bar{t}$ & $\begin{array}{r}4 \\
16 \\
5\end{array}$ & \pm & $\begin{array}{l}\text { Ruptured aneurysm } \\
\text { Postoperative meningitis } \\
\text { Carotid occlusion and } \\
\text { cerebral infarction }\end{array}$ \\
\hline $\begin{array}{l}43 / 66 \\
46 / 66 \\
59 / 66\end{array}$ & $\begin{array}{l}\mathbf{F} \\
\mathbf{F}\end{array}$ & $\begin{array}{l}59 \\
52 \\
62\end{array}$ & $\begin{array}{l}+ \\
+\end{array}$ & $\begin{array}{r}15 \\
3 \\
5\end{array}$ & $\bar{t}+$ & $\begin{array}{l}\text { Ruptured aneurysm } \\
\text { Ruptured aneurysm } \\
\text { Ruptured aneurysm }\end{array}$ \\
\hline
\end{tabular}

\section{Discussion}

Focal myocytolysis is a distinctive lesion seen most frequently in association with myocardial infarction, from which it must be distinguished (Schlesinger and Reiner, 1955). Frank infarction was not seen in the 18 cases of this series. The characteristic features of myocytolysis are loss of sarcoplasm from small areas of muscle, with retention of the sarcolemma, stroma, muscle nuclei, and lipofuscin granules; coagulative necrosis is not seen and the sarcoplasm seems to have been dissolved (Special Plate, Figs. 1 and 2).

This condition has also been found in patients dying of insulin shock and poliomyelitis (Schlesinger and Reiner, 1955). The lesion described as "necrosis" by Eichbaum and Bissetti (1966) in patients dying with head injuries may be of the same type. Two papers which may describe similar damage are those of Neuburger (1933) concerning death in young epileptics and of Burch et al. (1960), who briefly mention myocardial damage in a patient dying with subarachnoid haemorrhage. It is surprising that this lesion has not been more frequently described in cases of intracranial haemorrhage, as the majority of recent papers on E.C.G. abnormalities and brain lesions have concerned patients with cerebrovascular accidents. The normal gross appearance of the myocardium may be a partial explanation, as multiple blocks would not be examined. Some local factor occurring in the West of Scotland (Crawford and Crawford, 1967) might predispose the population to the development of heart damage, but E.C.G. changes in similar patients have been reported from many countries. Thus Burch et al. (1954) described E.C.G. changes in patients in the U.S.A. with cerebrovascular accidents, and among many others there are papers from U.S.S.R. (Popov, 1955), China (Kung et al., 1958), South Africa (Hersch, 1964), Finland (Koskelo et al.,
1964), U.K. (Srivastava and Robson, 1964), and Japan (Tomomatsu et al., 1964).

Focal myocytolysis may cause changes in the E.C.G.; the two patients in the present series on whom E.C.G.s were performed had considerable changes. One was reported as showing "anterior infarction," but this was not confirmed when the heart was examined at necropsy, and focal myocytolysis was the only evidence of myocardial damage. It is possible that this lesion could account for some of the reported E.C.G. abnormalities.

The cause of the myocardial damage is not known. Four possible explanations are vagal overactivity, sympathetic overactivity, a combination of these two, or an excessive release of catecholamines. There is clinical or experimental evidence in favour of all these theories as applied to E.C.G. changes.

Clinically there is good evidence of vagal overactivity, since patients with brain damage of ten have bradycardia, pulmonary oedema, and peptic ulceration, and Cropp and Manning (1960) thought that such vagal action might cause the known E.C.G. changes. Atropine may improve the E.C.G. picture in man (Shuster, 1960; Connor, 1965) and prevent abnormalities appearing in mice subjected to head injury (Jacobson and Danufsky, 1954). Section of the cervical cord above the sympathetic outflow will cause abnormal E.C.G.s to become normal when the abnormalities have been caused by stimulation of the brain in cats (Porter et al., 1962). Burch et al. (1960) suggested that the ischaemic changes in the E.C.G. in man might be due to "intense sympathetic tone." A combination of vagal and sympathetic overactivity was thought to be the cause of E.C.G. abnormalities by Visscher et al. (1956).

With regard to excess catechol activity, Hockman et al. (1966) believed that noradrenaline concentration in the heart was the probable cause of the E.C.G. changes in dogs following brain stimulation, and they noted that propranolol caused a return to normal. Shkhvatsabaia and Men'shikov (1962) found the level of catechols to be increased in the heart and decreased in the adrenals of animals after brain stimulation. There are rather inconclusive results regarding urinary levels of catechols in man after cerebrovascular accidents (Tomomatsu et al., 1964).

Finally, Melville et al. (1963), as a result of their experimental stimulation of the hypothalamus in cats, found evidence suggesting that the vagus, the sympathetic, and noradrenaline were all responsible in part for the E.C.G. pattern they observed.

The clinical importance of the E.C.G. changes has been underestimated. The original emphasis was on the danger of patients with a subarachnoid haemorrhage being denied the possible benefits of surgery because of an abnormal E.C.G. The papers by Koskelo et al. (1964) and Hoffbrand and Morgan (1965) are alone in suggesting that the abnormal E.C.G. in patients with brain damage may indicate cardiac dysfunction. Dubo et al. (1967) found a raised level of serum creatine kinase in many patients with strokes and head injuries. The enzyme was always of the type originating in cardiac and skeletal muscle, and Connor (1967) suggested that the heart was the most likely source. Patients with intracranial lesions from which recovery is possible may sometimes die of heart damage, and it would be of value to discover a method of prevention. This might be the administration of drugs to reduce the activity of the parasympathetic or sympathetic nervous systems or to block an excess of catecholamines. If such a method could be found, it should prevent death from cardiac arrest or arrhythmia, pulmonary oedema and subsequent bronchopneumonia, and cerebral hypoxia, which can only make the original intracranial damage worse.

The cause of focal myocytolysis is not clear. As stated above it is often associated with larger areas of coagulative necrosis, though this was not found in the present cases. Focal myocytolysis may owe its distinctive histological features to the 
small size of the lesions or to a slow rate of development and, like myocardial infarction, may be a "pluricausal cardiopathy."

I am grateful to Professor J. R. Anderson and Dr. A. T. Sandison for their help and encouragement in preparing this paper.

\section{REFERENCES}

Aschenbrenner, R., and Bodechtel, G. (1938). Klin. Wschr., 17, 298. Burch, G. E., De Pasquale, N., and Malaret, G. (1960)."Ann. intern. Med., 52, 587 .

Burch, G. E., Meyers, R., and Abildskov, J. A. (1954). Circulation, 9, 719.

Connor, R. C. R. (1965). Personal observations.

Connor, R. C. R. (1967). Lancet, 2, 991.

Crawford, T., and Crawford, M. D. (1967). Lancet, 1, 229.

Cropp, G. J., and Manning, G. W. (1960). Circulation, 22, 25.

Dubo, H., Park, D. C., Pennington, R. J. T., Kalbag, R. M., and Walton, J. N. (1967). Lancet, 2, 743 .

Eichbaum, F. W., and Bissetti, P. C. (1966). Proceedings of 5th International Congress of Neuropathology, p. 1016. Amsterdam.
Hersch, C. (1964). Brit. Heart 7., 26, 785.

Hockman, C. H. Mauck, H. P., and Hof, E C. (1966). Amer. Hear 7., 71, 695 .

Hoffbrand, B. I., and Morgan, B. D. G. (1965). Lancet, 1, 844

Jacobson, S. A., and Danufsky, P. (1954). F. Neuropath. exp. Neurol., 13, 462 .

Koskelo, P., Punsar, S., and Sipilä, W. (1964). Brit. med. F., 1, 1479.

Kung, L. S., Huang, T. K., Chu, H. Y., and Koang, N. K. (1958). Chin. med. $7 ., 76,445$.

Melville, K. I., Blum, B.,

Neuburger, K. T., (1933). Frankfurt. Z. Path., 46, 14

Peuburger, K. T. (1955). Ter. Arkh., 27, 45 .

Porter, R. W., Kamikawa, K., and Greenhoot, J. H. (1962). Amer. Hean 7., 64, 815 .

Russeli, N. L. (1956). F. med. Lab. Technol., 13, 484.

Schlesinger, M. J., and Reiner, L. (1955). Amer. J. Path., 31, 443.

Shuster, S. (1960). Brit. Heart F., 22, 316.

Shkhvatsabaia, I. K., and Men'shikov, V. V. (1962). Kardiologia (Moscow), 2, No. 6, p. 27.

Srivastava, S. C., and Robson, A. O. (1964). Lancet, 2, 431.

Trivastava, S. C., and Robson, A. O. (1964). Lancet, 2, 431.

Visscher, M. B., Haddy, F. J., and Stephens, G. (1956). Pharmacol. Rev., 8, 389.

\section{Preliminary Communications}

\section{Use of Dexamethasone in Cerebral Malaria}

\author{
Brit. med. F., 1968, 3, 31-32
}

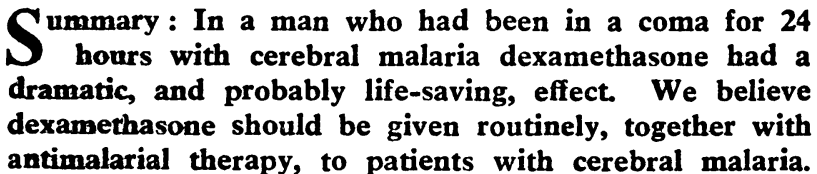

\section{INTRODUCTION}

The mortality rate in cerebral malaria has continued to be considerable even though the introduction of haemodialysis in the treatment of patients with severe malaria who develop uraemia and renal failure has enabled such patients to be kept alive, in most instances until kidney function recovers (Jackson and Woodruff, 1962). The principal obstacle to recovery is usually continued coma and the respiratory infection which frequently complicates it. We recently treated a patient in deep coma with Cheyne-Stokes breathing whose prognosis appeared to be very grave. At this stage dexamethasone was administered intravenously with the object of reducing the cerebral oedema which so often is a major pathological feature in cerebral malaria. The response was so dramatic that we suggest that use of this drug might become standard practice in cases of this kind. We are not aware of other reports on use of dexamethasaone in this regimen for cerebral malaria having so far appeared in the literature, and for this reason we consider it important to draw attention to this case.

\section{CASE History}

The patient, a 40-year-old man, had spent a month on a shooting expedition approximately 150 miles $(240 \mathrm{~km}$.) to the east of Nagpur, India; he had never visited any part of Africa. He arrived in Britain by air, having for the previous 7 to 10 days felt unwell with headache, aches and pains of the limbs, and attacks of shivering ; there is documentary evidence that three days before his arrival he had had a temperature of $102^{\circ} \mathrm{F}$. $\left(38.9^{\circ} \mathrm{C}\right.$.) ; on this day a blood film had been examined, but no malarial parasites had been noted in it and he had been given treatment with Achromycin V in doses of $250 \mathrm{mg}$. six-hourly; of this it seems he took a total of $1.5 \mathrm{~g}$. On arrival in Britain he had, with help, managed to reach his destination, the residence of a friend, who immediately called a medical practitioner who had the patient admitted to a nursinghome. There a blood film was examined and malaria parasites were found in it. The patient was given $600 \mathrm{mg}$. of chloroquine by mouth and managed to swallow the dose ; in spite of this, five hours later he was in coma and arrangements were made for his transfer to the Hospital for Tropical Diseases.

On admission he was comatose, unable to speak, and restless; and at times he was struggling, but he momentarily ceased to do so when his name was loudly called; he resisted medical examination. An hour later his coma became deeper and there was no response when his eyelashes were touched. A blood film at this time showed that $5 \%$ of erythrocytes were parasitized with Plasmodium falciparum. His blood urea on admission was $84 \mathrm{mg} . / 100 \mathrm{ml}$., plasma sodium $128 \mathrm{mEq} / \mathrm{l}$, and potassium $3.4 \mathrm{mEq} / \mathrm{l}$. An intravenous drip infusion was set up and through this $200 \mathrm{mg}$. of chloroquine was administered in 45 minutes; a further $100 \mathrm{mg}$. was given six hours later, and three hours later still a blood film showed only $0.1 \%$ erythrocytes parasitized. The temperature on admission was $104^{\circ} \mathrm{F}$. $\left(40^{\circ} \mathrm{C}\right.$.), and 18 hours later it was still $102^{\circ} \mathrm{F}$. $\left(38.9^{\circ} \mathrm{C}\right.$.). During these 18 hours he continued to be critically ill, was completely unconscious, and responded only to painful stimuli. There, were extensor plantar reflexes, and 12 hours after admission-that is, after he had been unconscious for approximately 16 hoursthere followed a period in which respiration from time to time took on Cheyne-Stokes characteristics with considerable periods of apnoea.

During the 12 hours following admission he was given $1,500 \mathrm{ml}$. of fluid intravenously and the urinary output was $1,300 \mathrm{ml}$., but at the end of this 12-hour period the blood urea remained $84 \mathrm{mg} . /$ $100 \mathrm{ml}$. In view of his critical condition, continuing deep coma, and the possibility that dialysis might become necessary he was transferred to the intensive care unit. Here the question of administering dexamethasone intravenously was considered, and in view of the fact that the malarial infection was already satisfactorily controlled and no evidence of respiratory infection was presentthis possibility having already been covered by the previous administration of tetracycline-it was decided that dexamethasone administration could not aggravate any infection and that its effect in diminishing cerebral oedema could be valuable. Twenty hours after admission-that is, after he had been in coma for approximately 24 hours-10 mg. of dexamethasone was injected intravenously. Four hours later coma had sufficiently lightened for the patient to ask for a drink, and 12 hours later he was fully conscious and ate breakfast. Dexamethasone in doses of $4 \mathrm{mg}$. was administered intravenously on two occasions during the 24 hours following the initial dose.

Progress thereafter continued uninterruptedly. During the succeeding four days the plasma urea dropped from 84 to $26 \mathrm{mg}$./ 